\title{
ISLAMIC MICROFINANCE INITIATIVES TO ENHANCE SMALL AND MEDIUM ENTERPRISES IN INDONESIA From Historical Overview to Contemporary Situation
}

\author{
Muhammad Syafii Antonio \\ Tazkia University College of Islamic Economics, Jakarta
}

\begin{abstract}
This paper highlights the policies and institutional setting of Small and Medium Enterprises (SME) development in Indonesia, followed by a discussion on the players in Islamic microfinance. Emphasis has been given to the potential role of Baitul Mal wa Tamwil (BMT, Islamic cooperative) as a strategic community-based micro lending initiative. The importance of Islamic microfinance initiatives as part of national program for the development of SMEs in Indonesia is also discussed. This paper argues that Islamic microfinance initiatives in Indonesia could represent an alternative source of finance for SMEs. The role of SMEs, especially after the Asian monetary crisis, was considered a safety valve for the national economic recovery both in enhancing economic growth as well as in reducing the unemployment rate. Credit distributed to SMEs has minimum risk and has sounder and better performance compared to larger enterprises. However, although having a significant role, SMEs actually have serious problems particularly as related to their capability in accessing formal financial institutions. This paper concludes by identifying the potential linkages between players in Islamic microfinance and highlights some critical points in their activities.
\end{abstract}

Keywords: Small and medium entreprises, Islamic microfinance, baitul mal wa tamwil.

\section{Introduction}

The role of small and medium enterprises (SMEs), especially after the Asian monetary crisis in late 1990s, was considered a safety valve for the national economic recovery both in enhancing economic 
growth as well as in reducing the unemployment rate. During $2000-$ 2011, the value creation of SME sectors increased significantly while large enterprises decreased. SMEs also contributed about $87.9 \%$ to the Indonesian Gross Domestic Product in 2011 compared to the contribution of large business enterprises. SME sectors could absorb about 98 million workers (99.4\% of the labor force) and provide about $43.8 \%$ of commodity needs and national services. ${ }^{1}$ The Bank of Indonesia also acknowledged that credit distributed to SMEs has minimum risk and has sounder and better performance compared to larger enterprises. ${ }^{2}$ In concurrence with the Bank of Indonesia, other studies also revealed that the Indonesian economy could not depend mostly on larger enterprises and SMEs were more resilient to the crisis compared to larger businesses. ${ }^{3}$ However, instead of having a significant role, SMEs actually have serious problems particularly as related to their capability in accessing formal financial institutions. It is in this context that this paper will identify and explore the emergence of Islamic microfinance initiatives that could represent an alternative source of finance for Small and Medium Enterprises.

This paper highlights the policies and institutional setting of SME development in Indonesia, followed by a discussion on the players in Islamic microfinance. Emphasis has been given to the potential role of baitul mal wa tamwil (BMT; literally "House of Funds and Finance"; terminologically "Islamic cooperative") as a strategic community-based micro lending initiative. The importance of Islamic microfinance initiatives as part of national program for the development of SMEs in Indonesia is also discussed. This paper concludes by identifying the potential linkages between players in Islamic microfinance and highlights some critical points in their activities.

\footnotetext{
1 The Bank of Indonesia, "Credit Crunch in Indonesia After the Crisis: The Facts, Causal Factors and Policy Implications," Internal discussion paper published by Department of Economy and Monetary Policy, the Bank of Indonesia (2001).

2 Ibid.

3 See for instance Tambunan, Manggara. "Melangkah ke Depan Bersama UKM," Paper presented at Economic Debate ESEI, Jakarta, September 15-16 (2004).
} 


\section{Overview of Policies on Small Business Development}

\section{Development of SMEs in Indonesia}

SMEs have played a significant role in Indonesia's economy for many decades and there are numerous reasons for this. First, there is a high proportion of SMEs in the economy, as both the number of enterprises and the economic output is high. According to the Central Bureau of Statistics, since 1998 Indonesia has had more than 37 million SME accounts, which contributed $60 \%$ to the Gross National Product (GNP) and constituted more than $95 \%$ of the total number of enterprises in the country. ${ }^{4}$ Second, SMEs are a major source of employment. For example, Shujiro Urata of the Japan International Cooperation Agency (JICA) and Timberg noted that in recent years the number of employees involved in SMEs exceeded $90 \%$ of the total workforce. ${ }^{5}$ This figure is expected to grow due to an accelerating rate of new SMEs being formed and also the expansion of existing enterprises. ${ }^{6}$

SME development in Indonesia has been connected to some contentious issues, such as the 'affirmative action' policies of fostering indigenous entrepreneurs (mostly Muslims) and various poverty eradication programs. Historically, there were two major initiatives related to affirmative action: the Benteng (Bastion) program in the 1950s, and asas pemerataan ('even distribution principle') of Soeharto's New Order period. ${ }^{7}$ The Benteng program was intended to promote the dominance of small-scale indigenous entrepreneurs' in the import sector and it was first implemented by the Natsir cabinet (September

\footnotetext{
${ }^{4}$ Badan Pusat Statistik (Central Bureau of Statistics), Profile of Establishment with Legal Entity, (Jakarta: Badan Pusat Statistik, 2000), Table (A) and after. See also, Swasono, Sri Edi,' Kedaulatan Rakyat, August 5, 2002, 'Prospek dan Perkembangan Perekonomian Rakyat: Antara Kedaulatan Rakyat dan Kedaulatan Pasar'.

5 "Perbankan Nasional Anaktirikan Usaha Kecil Menengah," Kompas, July, 252002. Also Thomas Timberg, "Strategy of Financing Small and Medium Enterprises in A New Economic Environment," (Paper presented at the conference on The Indonesian Economic Recovery in Changing Environment, held by Faculty of Economics, University of Indonesia on its $50^{\text {th }}$ anniversary, Jakarta, 4-5 October, 2000). See also Timberg, "Risk Management; Islamic Financial Policies Islamic banking and Its Potential Impact," An International Conference on Best Practice (2006).

${ }^{6}$ Badan Pusat Statistik (Central Bureau of Statistics), Profile of Establishment with Legal Entity (Jakarta: Badan Pusat Statistik, 2006).

${ }^{7}$ Richard Robison, The Rise of Capital (Sydney: Allen \& Unwin, 1986), pp. 44-46.
} 
1950-March 1951) but was most enthusiastically conducted by Ishaq Tjokrohadisoerjo, the Minister of Economic Affairs in the Ali Sastroamidjojo cabinet (August 1953-November 1954). However, the program failed due to insufficient regulation and abuse of the licensing system. ${ }^{8}$ Many Benteng enterprises did not use the import licenses themselves, but rather sold them to established importers, most of which were Chinese-controlled. Often these arrangements became known as 'Ali Baba' companies. 'Ali' (a reference to a pribumi or 'indigenous' Muslim) obtained the license through the Benteng program while 'Baba' (the Chinese entrepreneur) operated the business and took most of the profits, thus defeating the purpose of enhancing the economic power of Muslim businesspeople. ${ }^{2}$ The Benteng program was eventually scrapped by the Djuanda cabinet in 1957.10

Soeharto launched his own version of an affirmative action policy in the mid-1970s. Following the Malari riot on 15 January 1974, which was sparked by, among other things, a resentment towards non'indigenous' economic domination, significant changes in policy were adopted in the Garis Besar Haluan Negara (GBHN, Broad Outlines of State Policy) in 1978. ${ }^{11}$ The GBHN stated that pemerataan (equality) was to become a guiding principle in development policy, alongside high economic growth and national stability. At least seven special programs in the form of Instruksi Presiden (Inpres, Presidential Instructions), were initiated as a means to bring about more equitable wealth distribution. These distribution programs covered a wide range of areas, including rural development, affordable public health, education, reforestation and public works. ${ }^{12}$

To alleviate poverty, Soeharto introduced various programs and credit schemes, including: (1) Inpres Desa Tertinggal (IDT), the

\footnotetext{
${ }^{8}$ David L. Bevan, Paul Collier and Jan W. Gunning, The Political Economy of Poverty, Equity and Growth Nigeria and Indonesia (New York: Oxford University Press, 1999), p. 221.

${ }^{9}$ Robison, Indonesia: The Rise of Capital, p. 46.

${ }^{10}$ Ibid.

${ }^{11}$ Shortly, after the incident of Malari some significant affirmative policies have been taken place. Unfortunately, these policies apparently only political in nature, without any firm and sincere implementation afterwards. For more details refer Business News, No. 1, Jan/Feb. (1974), pp. 16-18.

12 Surbakti, Ramlan, "Formal Political Institutions," in Richard W. Baker, et.al., (eds), Indonesia the Challenge of Change (Singapore : ISEAS, 1999), pp. 73-74.
} 
presidential decree to alleviate backward villages, (2) the establishment small industry centers, Lingkungan Industri Kecil (LIK); and (3) introducing various subsidized credit schemes. Soeharto also urged state enterprises, Badan Usaha Milik Negara (BUMN), to assist smallscale business firms through a bapak angkat (foster parent) mechanism, and obliged BUMN to promote sub-contacting schemes with smallscale industries. The government also recommended that large enterprises sell shares to cooperatives, including the industrial cooperatives (both Koperasi Industri Kecil and Koperasi Industri Kerajinan Rakyat) to improve their capital base. Lastly, the New Order obliged all state and private banks to allocate $20 \%$ of their portfolio to small business enterprises. ${ }^{13}$

\section{Institutional Setting of Small Business and Microfinance in Indonesia}

\section{Philosophy of Islamic Microfinance}

The discussion on Islamic banking and microfinance will begin by identifying the philosophical background for the involvement of Islamic financial institutions in microfinance, their institutional settings and strategies for promoting small and micro enterprises. Although the main focus of Islamic banking is economic and financial intermediation, the system can only be fully comprehended in the context of social justice, equitable distribution concepts, and ethics. The individual and collective good, such as respect for property rights, sharing the risk and rewards, the sanctity of contracts and concern for the lower-income groups in society are also among the main principles underlying the Islamic banking system. Islamic small and microfinance programs share these principles with Islamic banks. As Dhumale and Sapcanin noted, 'They [Islamic banks and microfinance] may complement each other in both ideological and practical terms'. ${ }^{14}$

In line with this philosophy, most Islamic commercial and rural banks in Indonesia include in their formal objectives the empowerment of small and medium enterprises. Bank Muamalat Indonesia (BMI), for instance, states in its corporate mission statement

\footnotetext{
${ }^{13}$ Marisol Ravicz, Searcbing for Sustainable Microfinance: A Review of Five Indonesian Initiatives (Development Economics Research Group, World Bank working paper (1996), pp. 46.

${ }_{14}$ Rahul Dhumale and Amela Sapcanin, An Application of Islamic Banking Principles to Microfinance, Technical Note (Washington: World Bank, n.d), p. 1.
} 
that it is 'committed to provide the best services according to the government policies and shariah (Islamic law). This mission is implemented by identifying the needs of our clients and offering them various kinds of products and services, and is focused on promoting small and medium scale businesses'. ${ }^{15}$ The same sentiment had been enunciated by Rizqullah, the former head of BNI-46's Islamic banking division, stating that 'BNI-Shari'ah will be committed 100\% to small and micro enterprises'. ${ }^{16}$ To him, SME is low risk and is more crisis resilient than corporate lending. During its grand opening ceremony, the Islamic branch of Bank Danamon promised to dedicate $80 \%$ of its lending to small and medium enterprises. ${ }^{17}$ Some Islamic banks and Islamic units in conventional banks even incorporated the commitment toward small and medium finance into their motto. Bank Syariah Mandiri (BSM), for example, has the slogan of 'lebih adil dan menenteramkan' (more just and reassuring). ${ }^{18}$

From the marketing point of view, the idea of small and medium enterprises is also a saleable theme. According to Hermawan Kertajaya of Mark Plus Marketing Consultancy, there are two segments in the Islamic banking customer base: the 'emotional market' and the 'rational market'. ${ }^{19}$ The emotional market is driven mainly by a spirit to implement the Islamic principles in financial affairs as well as a motivation to foster small and medium enterprises. On the other hand, the rational market is the group that is primarily driven by a desire for better service and higher returns.

\section{Categorization and Players in SMEs}

In general, relations between SMEs and financial institutions can be categorized as either formal or informal. Formal financial institutions take two forms: bank and non-bank. According to the Banking Act No. 10/1998, only Bank Umum (commercial banks) and Bank Perkreditan Rakyat (rural banks) are classed as 'banks'. Non-bank formal financial institutions include various types of Lembaga Dana Kredit Pedesaan (LDKP, village-based institutions for small enterprise

\footnotetext{
${ }^{15}$ BMI, Annual Report, 1996 and 2006.

16 Republika, June 24, 2002.

${ }^{17}$ Kompas, June 29, 2002.

18 BSM, Annual Report, 2000 and 2006.

${ }^{19}$ BMI, Annual Report, 2000 and 2006.
} 
financing) and cooperatives. Informal financial institutions cover almost unlimited forms of saving-lending initiatives in society, such as Kelompok Swadaya Masyarakat (KSM, people's self-help groups), Kelompok Simpan Pinjam (KSP, saving and credit groups), Lembaga Swadaya Masyarakat (NGOs, non-governmental organizations) and KSM-based BMT. The categorization of Small and Micro Financial Institutions in Indonesia is summarized in table 1.

Table 1: Categorization of Small and Micro Financial Institutions in Indonesia

\begin{tabular}{llll}
\hline \multicolumn{2}{c}{ Formal } & & Informal \\
\hline Bank & Non-Bank & KSM & \\
Commercial Bank & LDKP & LSM & \\
Rural Bank & Co-operative & BMT &
\end{tabular}

Source: Antonio, unpublished PhD thesis, University of Melbourne, 2004.

In addition to those mentioned above, Yusoff stated that micro credit programmes are in fact run by various institutions, including government-related institutions which act as poverty reduction agents, NGOs - lending as a primary or side programme, not-for-profit private institutions, and commercial institutions. ${ }^{20}$ Table 2 shows a summary of four different types of micro credit operators.

Table 2: Examples of Micro Credit Operators

\begin{tabular}{ll}
\hline Classification & Institution \\
\hline $\begin{array}{l}\text { Government-related } \\
\text { agencies }\end{array}$ BRI & BRI (Indonesia), AIM, BAAC (Thailand) \\
& $\begin{array}{l}\text { Tau Yew Mai (Vietnam), Diocesan } \\
\text { Development Services (Africa) }\end{array}$ \\
Not-for profit & $\begin{array}{l}\text { Grameen Bank, Rural Credit and } \\
\text { institutions }\end{array}$ \\
$\begin{array}{l}\text { Cooperative Foundation (China), BancoSol } \\
\text { (Bolivia) }\end{array}$ \\
Commercial & $\begin{array}{l}\text { Bank Shinta Daya (Indonesia), Bank } \\
\text { Dagang (Indonesia) }\end{array}$ \\
\hline Source : Yusoff et al., "A Study on the Possibility of Mosque Institution."
\end{tabular}

20 Asry Yusoff et al., "A Study on the Possibility of Mosque Institution Running a Micro-Credit Programme Based on the Grameen Bank Group Lending Model: The Case of Mosque Institution in Kelantan, Malaysia," (Paper Presented on the $6^{\text {th }}$ International Conference on Islamic Economics and Finance in Jakarta, 21-24 November 2005). 
Players in Islamic small and microfinance can be classified into several categories based on their credit and capital size and source of funds (see table 3). Based on capital and credit size, there are Islamic commercial banks (ICBs), Bank Perkreditan Rakyat Syariah (BPRS, Islamic rural banks) and BMT. Among ICBs we also find private and state-owned banks as well as Islamic branches of conventional banks. Both ICBs and BPRS are heavily regulated by the Bank of Indonesia, while BMT are monitored by the Lembaga Pengembang Swadaya Masyarakat (LPSM or Institute for the Development of Self-Help Groups).

Table 3: Islamic Banks and Finance Companies in Indonesia According to Their Size of Capital and Credit Limit

\begin{tabular}{lll}
\hline Type of Islamic Bank & Minimum Capital & $\begin{array}{l}\text { Size of Credit per } \\
\text { customer }^{21}\end{array}$ \\
\hline ICB & $\begin{array}{l}\text { Rp.1 trillion ( for new } \\
\text { license) }\end{array}$ & $\begin{array}{l}\text { Rp. } 100 \text { million and } \\
\text { higher }\end{array}$ \\
BPRS & $\begin{array}{l}\text { Rp } 500 \text { million- Rp. } \\
2 \text { billion }\end{array}$ & Rp. $5-100$ million \\
& Rp. $10-100$ million & $\begin{array}{l}\text { Rp. } 100.000 \text { to Rp. } \\
10 \text { million }\end{array}$ \\
BMT & & \\
\hline
\end{tabular}

\section{Players in Islamic Microfinance}

One of the most important institutions in Islamic small and microfinance is the BMT. The term BMT originated from the treasury system at the time of the Prophet Muhammad, which was called Bayt al-Mäl. Bayt al-Mäl, served as the treasury for national budgeting as well as maintaining stability of money supply. The Bayt al-Mäl also functioned as a payment centre for the government in dealing with local and international agencies and individuals. The practice of Bayt alMăl developed significantly during the time of the second caliph, 'Umar bin Khattāab. During his period (624-634 AD) branches of the Bayt al-Mäl were set up in every capital city of the caliphate to collect taxes, the spoils of wars and administrative fees, as well as to raise

${ }^{21}$ The maximum lending limit of Islamic banks is subject to their size of capital (legal lending limit). 
charitable funds. They also financed infrastructure and paid the wages and salaries of state officers. ${ }^{22}$

Different from the original concept of Bayt al-Mäl, the main objective of BMTs is to provide an Islamic alternative to micro enterprises that for decades have been the victims of moneylenders. Most micro entrepreneurs lack access to formal banking institutions, conventional and Islamic alike. The first initiative of BMT in Indonesia was pioneered by Islamic NGO activists, such as Zainal Muttaqien, Istar Abadi, Iwan Kusuma Hamdan, Aries Mufti, Rizal Kusumanegara and Syafii Antonio in 1992.23 As the first BMT, Bina Insan Kamil (BIK) proved that micro lending could be carried out profitably and in a sustainable form. With capital of Rp. 4.7 million (equal to US $\$ 1,880$ at that time), BIK was successful in mobilizing funds and channeling credit into micro enterprises in the Eastern region of Jakarta. Within 30 months of operation BIK managed to collect more than Rp. 400 million in deposits through the schemes of mudarabah deposits and wadi'ah savings. ${ }^{24}$ Following the success of BIK, other BMT were established in other parts of Jakarta and West Java. By the end of 1992 there were more than 30 BMTs throughout Indonesia. ${ }^{25}$

Interested in the strategic role of the BMT, Amin Aziz ${ }^{26}$ of Ikatan Cendekiawan Muslim Indonesia (ICMI, the Indonesian Association of Muslim Intellectuals) invited BIK managers to work closely with other prospective BMT groups and develop a national BMT system. However, BIK managers responded to the invitation reluctantly. The main reason for this unenthusiastic response was to avoid the use of BMTs as a political maneuver on the part of Azis (at that time, Azis was a close aide to former President Habibie and senior member of ICMI). As a result, BIK group established their own BMT linkages

\footnotetext{
${ }^{22}$ Hasanuz Zaman, SM., Economic Functions of an Islamic State; The Early Experience, $2^{\text {nd }}$ edition (Karachi: The Islamic Foundation, 1991).

${ }^{23}$ Personal interview with Aries Mufti, Jakarta, 17 May 2007.

${ }^{24}$ Mudarabab is a profit sharing mode of financing but the scheme can also be used to generate funding from the public in various types of saving and deposits. Wadi'ab is a trust deposit widely used in Islamic bank as a current account.

25 Personal interview with Rizal Muganegara, Director of BIK, Jakarta, 18 May 2007.

${ }^{26}$ Amin Aziz is one of the most important figures in the establishment of BMI. He is a senior member of central Board of MUI, and Muhammadiyah Economic Committee, and he used to be a senior member of PAN, a political party led by Amien Rais.
} 
named Pusat Penelitian dan Pengembangan Usaha Kecil (P3UK, the Centre for Research and Development of Small Business). As an alternative, Aziz formed Pusat Inkubasi Bisnis Usaha Kecil (PINBUK, Centre for Small Business Incubation) to provide an umbrella group for further BMT development in Indonesia. PINBUK initially was a task force of YINBUK (Yayasan Inkubasi Busnis Usaha Kecil, Foundation for Small Business Incubation) established jointly on 13 March, 1996, by ICMI, BMI and MUI (Majelis Ulama Indonesia, Indonesian Ulama Council). ${ }^{27}$ Despite accusations that Aziz was politicizing BMTs, the BMT movement gained momentum under his leadership and was declared a national program by President Soeharto on 7 December 1995.

With the support of Habibie from ICMI, Zainul Baharnoor from BMI and Hasan Basri from MUI, as well as the blessing of Soeharto, BMTs spread into cities and regions across Indonesia. PINBUK reported that by the end of 2002, there were more than 2,500 BMT units in operation. However, the widespread proliferation of BMTs cannot be credited to PINBUK alone. In fact, it is a result of scattered but complementary actions of Islamic micro finance centers such as P3UK, FES (Forum Ekonomi Syariah) Griya Arafa, and Amanah Ummat Foundation. ${ }^{28}$

Other NGOs that are actively involved in developing BMTs in Indonesia at the moment are the BMT Centre of Dompet Dhuafa and Microfin Indonesia. ${ }^{29}$ The BMT Centre was established in 14 June 2005 but now has more than 100 BMTs member, mostly in the form of cooperatives. Total assets of the BMT Center's members are more than Rp. 251 billion, with 1,626 employees. The BMT Center as a coordinating body aims to develop networks among members and develop the potential of BMTs. The institution remains nongovernmental, professional, and transparent and is overseen by

\footnotetext{
27 Agus Sumarno, "Skenario Pengembangan Jaringan Ekonomi Umat; Kaitannya BMT dan Sektor Riel," Baihaqi Abd Majid and Saifuddin A. Rasyid, (eds), Paradigma Baru Ekonomi Kerakyatan Sistim Syariah (Jakarta: Pinbuk, 2000), p. 242.

${ }^{28}$ Chamsiah Djamal, "Pengalaman BMT Dalam Mengentaskan Kemiskinan Umat," in Paradigma Baru Ekonomi Kerakyatan Sistim Syariah, in Ibid., p. 276.

29 Ersa Tri Wahyuni, "The Accountability of Islamic Microfinance Institutions: Evidence From Indonesia," in the Proceeding of First International Islamic Conference on Inclusive Islamic Financial Sector Development, p. 532 and onwards (Brunei Darussalam: University of Brunei Darussalam April, 17-19, 2007).
} 
independent people who are not BMT executive staff. The BMT Center initiative came from Dompet Dhuafa and is fully supported by a number of BMTs, mostly in Jakarta and Central Java. Currently the Centre cooperates with PT Permodalan National Madani (PT PNM), a state-owned enterprise that distributes funding of up to Rp. 15 billion to eligible BMTs. Members of the BMT Center need to submit their financial statement to meet the eligibility criteria in order to become a member or receive capital funding.

Similar to the BMT Centre is Microfin Indonesia. Established in 2005, Microfin Indonesia has 700 BMT partners. The cooperation varies from channeling funds, training for establishment, legal assistance and providing management consultancy. Microfin Indonesia has several branches mostly in big cities in Java. They have strong relations with Baitul Mal Muamalat (BMM, a Corporate Social Responsibility arm of BMI), as many of the founders of Microfin also come from BMM. Many BMT development programs from BMM are carried out by Microfin Indonesia. A recent program involved 107 BMTs from Java and Lampung, which joined a program that includes funding assistance, training and IT development support. Microfin also cooperates closely with the Ministry of Cooperatives and Small to Medium Enterprises. In 2003 and 2004, they distributed funding grants from the Ministry to 127 BMTs. ${ }^{30}$

The emergence of BMTs has had a significant impact on the development of Islamic financing in Indonesia. BMTs can use Islamic commercial and rural banks as their channeling networks particularly in areas where BPRS or commercial banks are absent. However, from a legal standpoint, the establishment of BMTs is quite problematic because they have no formal linkage to the national monetary system and are neither controlled by the Bank of Indonesia nor by the Ministry of Finance. Most BMTs were established initially as self-help groups or in the form of foundations. The crucial element of this informal status is with the funding activities of BMTs. They mobilize savings and deposits from the community without any obligation to produce formal regular monthly reports either to the public or to a supervisory body. The accountability of BMTs in many respects depends on the sincerity and good intentions of the management (see table 1-4).

${ }^{30}$ Ibid. 
Apart from the issue of legal concerns, the BMTs have had the chance to cover the needs of the poor or low-income members of society. As stated by Ascarya and Sanrego, ${ }^{31}$ figures show that BMTs, as part of other microfinance institutions, fit in with the nature and the needs of poor Indonesian people. BMTs also do not require customers to have any licenses or permits to run their businesses and that makes BMTs more suited to the poor.

Driven by this phenomenon, almost all Islamic centers for development of micro enterprises such as PINBUK, P3UK, the BMT Centre of Dompet Dhuafa, Microfin Indonesia and Amanah Ummat Foundation have urged BMTs to create a formal legal entity. The most advisable form is that of a cooperative or self-help group with special 'mother' institutions that provide guidance and monitoring, widely known as LPSM. With this new legal framework, BMTs represent one of the most appropriate lending institutions for addressing entrenched poverty in villages through the issuing of micro-credit on a commercial basis without violating the Islamic principles of transaction.

Table 4: Institutional and Infrastructure Conditions of Microfinance (Comparing BPR, BRI Units and BMT)

\begin{tabular}{|c|c|c|c|}
\hline Aspect & BPR \& BRI Unit & Cooperative & $\begin{array}{l}\text { Other MF } \\
\text { Institutions }\end{array}$ \\
\hline Regulation & Banking Law & Cooperative Law & $\mathrm{N} / \mathrm{A}$ \\
\hline Regulator & Bank of Indonesia & $\begin{array}{l}\text { Ministry of } \\
\text { Cooperative \& } \\
\text { SMEs }\end{array}$ & $\mathrm{N} / \mathrm{A}$ \\
\hline Supervision & Bank of Indonesia & $\mathrm{N} / \mathrm{A}$ & $\mathrm{N} / \mathrm{A}$ \\
\hline Insurance & Government & $\mathrm{N} / \mathrm{A}$ & $\mathrm{N} / \mathrm{A}$ \\
\hline Liquidity & Bank of Indonesia & $\mathrm{N} / \mathrm{A}$ & $\mathrm{N} / \mathrm{A}$ \\
\hline Rating & $\begin{array}{l}\text { Bank of Indonesia - } \\
\text { Soundness Rate }\end{array}$ & $\begin{array}{l}\text { Ministry of } \\
\text { Cooperation \& } \\
\text { SMEs }\end{array}$ & $\mathrm{N} / \mathrm{A}$ \\
\hline
\end{tabular}

\footnotetext{
31 Ascarya and Yulizar D. Sanrego, "Redefining Micro, Small and Medium Enterprises Classification and the Potency of Baytul Maal wa Tamwil Intermediary Institutions in Indonesia," in Syed Salman Syed Ali (ed.), Proceedings of First International Islamic Conference on Inclusive Islamic Financial Sector Development, Volume II (Brunei Darussalam: University of Brunei Drussalam, 17-19 2007), pp. 552-578.
} 


\begin{tabular}{llll}
\hline Aspect & BPR \& BRI Unit & Cooperative & $\begin{array}{l}\text { Other MF } \\
\text { Institutions }\end{array}$ \\
\hline \multirow{2}{*}{ Association } & $\begin{array}{l}\text { Perbarindo- } \\
\text { Asbisindo }\end{array}$ & $\begin{array}{l}\text { Main } \\
\text { Cooperative } \\
\text { Centre }\end{array}$ & $\begin{array}{l}\text { PINBUK/Credit } \\
\text { Union }\end{array}$ \\
\hline
\end{tabular}

Source: Didin Wahyudin, "Key Success Factors In Micro Financing," (Paper presented at Panel Discussion Microfinance Revolution: Future Perspective for Indonesian Market, Jakarta, 7 Dec, 2004).

Gebrekidan provides a clear feature of microfinance institutions (MFIs). ${ }^{32}$ He stated that MFIs in relation to other financial intermediaries have a special role and distinguishing features, as follows: (1) The primary objective of MFIs is to address the credit needs of those who are willing and ready to reduce their chronic poverty by engaging in farming and small scale production and service activities; ${ }^{33}$ (2) Beside provision of credit facilities, MFIs render managerial, marketing, technical and administrative advice to borrowers, by reaching borrowers at their place of work; (3) MFIs do not require collateral to extend credit in cash or in kind to peasant farmers and small entrepreneurs. Instead of peer group-leading schemes, character based loans and the promise of subsequent loans are the main motivations for repayment; ${ }^{34}$ (4) Saving requirements are introduced as a compulsory feature of lending activity and this saving requirement seems to serve as a motivator for repayment of loans since borrowers choose to repay the loan rather than losing the amount they saved. ${ }^{35}$

\footnotetext{
32 Gebrekidan, A., "The impact of micro financing institutions on the livelihood of the rural poor," Seminar Series (Nazareth, Ethiopia: Department of Business Management, Adama University, 2006).

33 Getahun Tafesse, "The PRSP initiative: implications to Ethiopia, United Nations. Economic Commission for Africa, UN," (Paper presented at ECA Workshop and training course on public intervention for poverty reduction and the PRSP in Addis Ababa, Ethiopia, 31 July- 2 August 2001).

34 Marguerite Robinson, The Microfinance Revolution: Sustainable finance for the poor (Washington, DC: The World Bank, 2001).

35 Tafesse, The PRSP initiative.
} 


\section{Islamic Microfinance Programs}

As explained in the previous sections, the Indonesian government has, from time to time, initiated several programs and subsidized credit schemes for small and micro enterprises through various state departments and agencies. Shortly after the Asian monetary crisis in late 1990s, the government also promoted a number of subsidized credit schemes of programmed credit. ${ }^{36}$ At the same time ICBs and BPRS could also participate in other programs as long as they did not violate Islamic principles. For instance, in 1998, BMI succeeded in launching a profit-sharing based, subsidized credit program named KKPA as a credit facility for cooperative members. The credit ceiling agreed by the Bank of Indonesia and the Ministry of Finance reached the amount of Rp. 30.7 billion. ${ }^{37}$ As a pilot project, this credit scheme has been distributed in coordination with 16 cooperatives and BMT in West Java, Central Java, and East Java. In November 1998 BMI also obtained approval from the Central Bank to disseminate the loans on a profit sharing basis for cooperatives (KKOP, Kredit Kepada Koperasi) and the amount of credit for the first stage was Rp. 10 billion. Another form of synergy between the Central Bank and ICBs is the project to heighten incomes for small farmers through the Farmer Enterprise Credit scheme. BMI proposed the concept of al-wakalah (mandate to perform) as the basis for credit distribution. The central bank responded positively by granting Rp. 27 billion for the first stage. ${ }^{38}$

Starting from 1997, BMI has also been trusted by Ministry of Cooperatives to carry out Proyek Peningkatan Kemandirian Rakyat (P2KER, the People's Economic Empowerment Project). ${ }^{39}$ This project was implemented in cooperation with four partners; Rābithat al-Ma'āhid al-Islāmīyah (RMI, a federation of NU-based traditional Islamic boarding schools or pesantren), Induk Koperasi Pondok Pesantren (Inkopontren, the Central Board of the Traditional Islamic Boarding Schools' Co-operatives), PINBUK and Pusat Pengkajian

\footnotetext{
${ }^{36}$ Zainul Arifin, Memahami Bank Syariah, Lingkup Peluang Tantangan dan Prospek, p. 97.

${ }^{37}$ BMI Annual Report, 1998 and 2006.

${ }^{38}$ Ibid.

${ }^{39}$ For more information regarding the P2KER program see "Panduan Unit Simpan Pinjam Syariah, Proyek Peningkatan Kemandirian Ekonomi Rakyat (P2KER)," (Unpublished booklet, Jakarta: Ministry of Cooperatives and Bank Muamalat, 1997/1998).
} 
Masyarakat dan Pesantren (P3M, Centre for Study of pesantren and society; it is a think-tank institute with close ties to NU). The main objective of this project is to accelerate the development of Unit Simpan Pinjam (USP, Islamic savings and lending units) at pesantren in Indonesia. By the beginning of 1999, more than 1,500 Islamic savings and lending units had been established at pesantren in 15 provinces. The project covers training programs for more than 3,000 management and executive officers and 160 staff of USP. Other activities include channelling of the working capital, in the amount of Rp. 16.68 billion, to the USP units as well as conducting monitoring programs and supervision of the distribution of the funds. ${ }^{40}$

Other efforts in promoting small and micro financing include strategic alliances with various local and international agencies and associations. Since 1996, BMI was again entrusted by a Kuwaiti-based NGO, the International Development Fund (IDF), ${ }^{41}$ to coordinate a specific program for small and micro enterprise development in selected provinces of Indonesia. The pilot project was carried out in the provinces of Lombok and Central Java. In the first stage, more than Rp. 286 million of IDF funds was allocated to 1,063 members of cooperatives and street vendors. BPRS Margi Rizki in Yogyakarta and BPRS Patuh Beramal in Mataram, Lombok, were chosen as the affiliate parties for the project. ${ }^{42}$

In 2007 BMM launched the KUM3 program (Komunitas Usaha Mikro Mustahik Muamalat, the Muamalat Micro Enterprises Community). With KUM3, BMM aimed to empower at least 11,000 micro enterprises by channelling Rp. 22 billion until the end of 2007.43 The establishment of BMM also served as a clear departure and separation of charity-based small and micro finance (SMF) with funds coming from zakāh (an Islamic tax for charity), and other forms of charity, from commercial-based SMF that used ordinary savings and deposits at market rates to finance the fund.

Along with those aforementioned initiatives, the government also launched economic package to stimulate small and micro finance. The

\footnotetext{
40 BMI, Annual Report, 1998, pp. 37-38, and see also BMI Annual Report 2006.

${ }^{41}$ The signing ceremony took place on December 6, 1996.

42 BMI, Annual Report, 1997, pp. 36-37.

${ }^{43} \mathrm{http}: / /$ satudunia.oneworld.net/article/view/150036/1/, last accessed on September $4,2007$.
} 
most appreciated national initiative to foster the development of small and micro finance in Indonesia is the obligation to have a minimum percentage of Kredit Usaha Kecil (KUK, Credit for Small Business) in credit portfolios. The initiative began in 1990 as a political-economic consequence of the reduction of the Bank of Indonesia's ability to subsidize a wide range of credits. According to the government's Decree No. 29/Jan/1990, all banks were required to extend at least $20 \%$ of their total credit portfolio to small enterprises. ${ }^{44}$ The main objective of this policy was to ensure a sufficient supply of funds would be channeled to small and micro enterprises group.

\section{Potential Networking and Linkage between Islamic Financial Institutions}

Another strategic program in promoting small and microfinance in Indonesia is the symbiotic relationship between different types of Islamic financial institutions (IFIs). The type of cooperation among IFIs consists of one out of at least five forms: equity placement, deposit placement, syndicated financing, credit channelling and extending credit to BPRSs or BMTs. The most common of these five practices are the first two. With these joint efforts, BPRSs and BMTs can access fresh funds from ICBs, hence strengthening their liquidity. At the same time they can also provide new investment ventures for ICBs that generate new income and extend the Islamic banks service networks. Another benefit of cooperation is to reduce the monitoring and supervisory costs of ICBs, particularly in locations where they do not have branches or representatives. The monitoring function is more economical if it is delegated to BPRS or BMT. The linkages and networks among Islamic financial institutions are depicted in table 5.

In the centre of the network (figure 1-1) are ICBs. ICBs are surrounded by BPRSs, and these in turn are at the centre of the BMT's orbit. These Islamic financial institutions obtain funds mainly from public depositors at commercial rates, and occasionally from various government and non-governmental organizations. Among government agencies actively involved in small business support are the Bank of Indonesia (Central Bank), the Ministry of Finance, the Ministry of Cooperatives, the National Planning Board for Development, the Ministry of Industry and International Trade, and the Ministry of Manpower and Transmigration. Under the Ministry of Finance, three

\footnotetext{
${ }^{44}$ Bank Indonesia, Sejarah Peranan Bank Indonesia Dalam Pengembangan Usaha Kecil, p. 77.
} 
state-owned enterprises (SOEs) are playing strategic roles in promoting small and micro enterprises: Bank Rakyat Indonesia (BRI), Permodalan Nasional Madani (PNM), and Bank Tabungan Negara (BTN).

\section{Some Critical Points of Islamic Microfinance Initiatives}

Having the nature of microfinance, it is clear that Islamic microfinance institutions could become an engine to accelerate SME businesses. However, a close investigation of the practices of Islamic small and micro financial institutions reveals several problems. Chief among these is the lack of coordination between ICBs and various government agencies and NGOs.

Table 5: Linkages of Islamic Small and Micro Finances in Indonesia

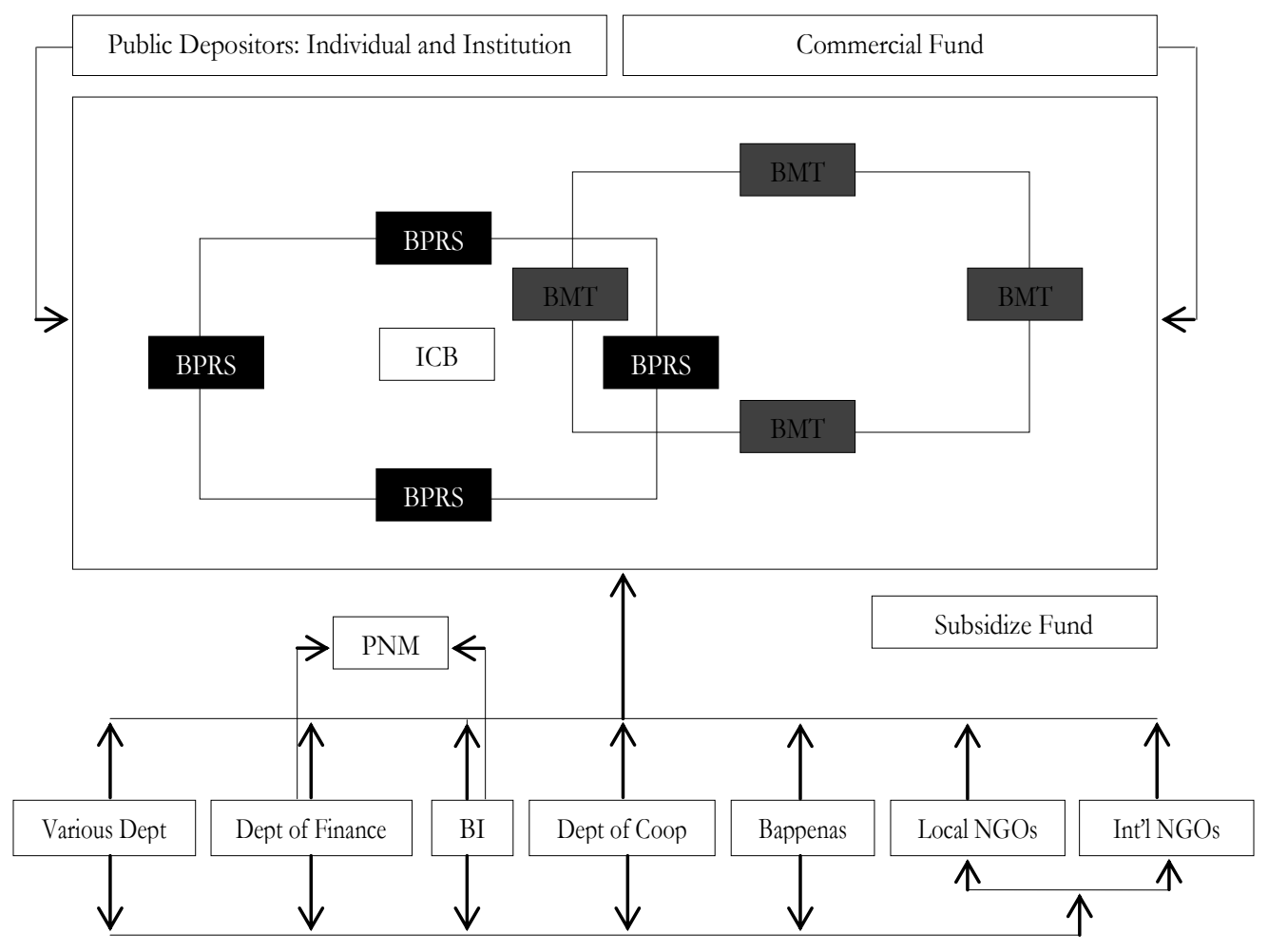

In terms of cooperation, almost every ICB is looking for a healthy and sound BPRS with which it can form a strategic alliance. In many cases, BMI and Bank Syariah Mandiri (BSM) are competing against 
each other in the search for sound and attractive BPRSs and BMTs. The BPRSs and BMTs also find themselves in a similarly competitive system in which they seek the most favourable ICB partners and conditions. The most obvious consequence of this - a survival of the fittest condition - is the lack of attention to small and financially insecure BPRS and BMTs. In fact this group is the one that needs the most attention and assistance.

Regarding technical aspects, almost all of the prevailing Islamic banks are applying corporate banking approaches to deal with small and micro enterprises. According to Mukhamad Yazid of Tazkia Research Centre and many other critics ${ }^{45}$ this approach constitutes one of the most fatal errors perpetrated by Islamic commercial and rural banks in Indonesia. The average cost to handle a big corporation is almost the same as tackling a small credit unit, although the latter has much less margin and profitability. As a consequence, if the ICB and BPRS do not restructure their approach to suit small and micro enterprises, the SMEs will constitute a burden and dealing with them will require a high cost of transaction. ${ }^{46}$

The other serious challenge faced by the Islamic banking industry in serving small and micro enterprises is the limitation on the size of its network and number of branches. Until the third quarter of 2011, there were only 11 fully-fledged Islamic banks and 24 conventional banks with Islamic branches. The total number of offices of ICBs is 1430, including head offices, main branches, sub-branches, Shariah service units and cash units. ${ }^{47}$ This constitutes very low penetration compared to the 378 conventional bank offices. At the rural banking level, a report by the Bank of Indonesia stated that Indonesia has 157 Islamic rural banks compared to 8,950 units of conventional rural banks. ${ }^{48}$

The limited numbers of Islamic bank offices is a serious obstacle for small and micro enterprises in remote areas and small villages to

\footnotetext{
${ }^{45}$ Personal interview Jakarta, July 12, 2007

46 Personal interview with Budi Wicakseno, the Marketing Director of BMI, May, 13, 2007.

47 The Bank of Indonesia, Islamic Banking Statistics (Jakarta: Islamic Banking Directorate, July 2007).

48 http://www.bi.go.id/biweb/Html/SekiTxt/T3x101.txt, retrieved on September 15, 2007.
} 
access Islamic finance. Some initiatives, however, have been taken by the Bank of Indonesia since 2006, including introducing an Office Channeling (OC) program, by which a conventional branch might introduce Islamic banking services on basic funding services such as receiving deposits and providing client information. In 2007, the Bank of Indonesia began gradually allowing the OC to disburse basic finance to their customers.

Another initiative to tackle the inadequate Islamic banking network is the introduction of ATM services. BMI, for example, is collaborating with Bank Central Asia to use that bank's 8888 automated teller machines (ATMs) for its own customers. Bank Syariah Mandiri (SBM) is similar to BMI and has adopted the same strategy. As the largest Islamic bank in the country, BSM formed a strategic cooperation with its parent company, Bank Mandiri, to allow access to its ATM network, allowing BSM customers to use a network which covers almost every city in Indonesia.

\section{Conclusion}

The previous sections have discussed the great impact that SMEs have on economic growth. Despite their success, SMEs have difficulty in obtaining financing services from the formal financial institutions. However, this limitation could be catered to by the existence of BMTs. This paper proves that BMTs have an opportunity to cover the SMEs business financing service. Apart from their positive contribution, BMTs have some deficiencies that need to be managed correctly in order to improve their services and develop the performance of the SMEs. The issue of coordination amongst other Islamic financial institutions is another primary issue that should be seriously considered. This issue could be approached by introducing or initiating Islamic financial schemes to SME enterprises so that they can uphold a strong strategic synergy between the Islamic banking industry and national programs.]

\section{Bibliography}

\section{Books and Articles}

Act No. 9/1995 about Small Enterprises.

Arifin, Zainul. Memahami Bank Syariah, Lingkup Peluang Tantangan dan Prospek, 2001. 
Badan Pusat Statistik. Profile of Establishment with Legal Entity. Jakarta: Badan Pusat Statistik, 2000.

Bank Bukopin Annual Report, 2002 and 2006.

Bank Indonesia. Sejarah Peranan Bank Indonesia Dalam Pengembangan Usaha Kecil.

Bevan, David L., Paul Collier and Jan W. Gunning. The Political Economy of Poverty, Equity and Growth Nigeria and Indonesia. New York: Oxford University Press, 1999.

BMI. Annual Report, 1996 and 2006.

BMI. Annual Report, 2000 and 2006.

BPRS Amanah Ummah Company Profile, 2002.

BRI. Annual Report, 2002 and 2006.

BSM. Annual Report, 2000 and 2006.

Dachlan, Rustam. "Pengembangan Kinerja BRI Unit." in Prosiding Lokakarya Lembaga Kenangan Mikro (LKM) Indonesia, Bogor, 4 - 5 July, 2000.

Dhumale, Rahul and Amela Sapcanin. An Application of Islamic Banking Principles to Microfinance, Technical Note. Washington: World Bank, n.d..

Djamal, Chamsiah. "Pengalaman BMT Dalam Mengentaskan Kemiskinan Umat." in Baihaqi Abd Majid and Saifuddin A. Rasyid (eds.). Paradigma Baru Ekonomi Kerakyatan Sistim Syariah. Jakarta: Pinbuk, 2000.

Panduan Unit Simpan Pinjam Syariah. "Proyek Peningkatan Kemandirian Ekonomi Rakyat (P2KER)." Unpublished booklet, Ministry of Cooperative and Bank Muamalat, Jakarta, $1997 / 1998$.

Patten, Rosengard R. and J. Johnston, D.E. "Microfinance Success Amidst Macroeconomic Failure: The Experience of Bank Rakyat Indonesia During the East Asian Crisis." World Development, Vol. 29, No. 6, (2000): pp. 1057-1069.

Ravicz, Marisol. "Searching for Sustainable Microfinance: A Review of Five Indonesian Initiatives.” Development Economics Research Group, World Bank working paper, 1996. 
RICA. "Pembiayaan UKM: Danamonn Simpan Pinjam, Studi Kasus RICA.” Rural Investment Climate Assesment, November 2005.

Robison, Richard. The Rise of Capital. Sydney: Allen \& Unwin, 1986.

Sumarno, Agus. "Skenario Pengembangan Jaringan Ekonomi Umat; Kaitannya BMT dan Sektor Riel." in Baihaqi Abd Majid and Saifuddin A. Rasyid (eds.). Paradigma Baru Ekonomi kerakyatan Sistim Syariah. Jakarta: Pinbuk, 2000.

Surbakti, Ramlan. "Formal Political Institutions." in Baker, Richard W., et al. (eds.). Indonesia: The Challenge of Change. Singapore: ISEAS, 1999.

Swasono, Sri Edi, "Prospek dan Perkembangan Perekonomian Rakyat: Antara Kedaulatan Rakyat dan Kedaulatan Pasar." Kedaulatan Rakyat, 5 August 2002.

Timberg, Thomas. "Risk Management; Islamic Financial Policies Islamic banking and Its Potential Impact." Paper presented at the International Conference on Best Practice, 2006.

Timberg, Thomas. 'Strategy of Financing Small and Medium Enterprises in A New Economic Environment." Paper presented at the conference on The Indonesian Economic Recovery in Changing Environment, held by Faculty of Economics, University of Indonesia on her $50^{\text {th }}$ anniversary, Jakarta, 4-5 October, 2000.

Wahyudin, Didin. "Key Success Factors In Micro Financing." Paper presented at Panel Discussion Microfinance Revolution: Future Perspective for Indonesian Market, Jakarta, 7 Dec, 2004.

Wahyuni, Ersa Tri. "The Accountability of Islamic Microfinance Institution: Evidence From Indonesia." in the Proceeding of First International Islamic Conference on Inclusive Islamic Financial Sector Development, The University of Brunei Darussalam April, 17-19, 2007.

Yusoff et al., Asry. "A Study on the Possibility of Mosque Institution Running a Micro-Credit Programme Based on the Grameen Bank Group Lending Model: The Case of Mosque Institution in Kelantan, Malaysia." Paper Presented on the $6^{\text {th }}$ International Conference on Islamic Economics and Finance in Jakarta, 21-24 November 2005. 
Zaman SM., Hasanuz. Economic Functions of an Islamic State: The Early Experience. $2^{\text {nd }}$ edition. Karachi: The Islamic Foundation, 1991.

\section{Newspapers and Internet Sources}

Business News. No. 1, Jan/Feb. 1974, 16-18.

http://www.bi.go.id/biweb/Html/SekiTxt/T3x101.txt, retrieved on September 15, 2007.

Kompas Daily. June 29, 2002.

Kompas July. 25 2002, 'Perbankan Nasional Anaktirikan Usaha Kecil Menengah.'

Media Indonesia. 860 Lembaga Keuangan Mikro Syariah akan direvitalisasi. 3 May 2006.

Republika Daily. June 24, 2002.

\section{Interviews}

Personal interview with Budi Wicakseno, the Marketing Director of BMI, May, 13, 2007.

Personal interview with Aries Mufti, May 17, 2007.

Personal interview with Rizal Muganegara, May 18, 2007.

Personal interview with Mukhamad Yasid, July 172007. 